\title{
ПРОГРАМИ МЕДИЧНОГО СТРАХУВАННЯ ТА ЇХ ОСОБЛИВОСТІ ЗА УМOB COVID-19
}

\author{
Тернопільський національний медичний університет \\ імені І. Я. Горбачевського МОЗ України, м. Тернопіль, Україна
}

\begin{abstract}
Мета: з'ясувати особливості програм медичного страхування за умов пандемії COVID-19.
Матеріали і методи. У роботі використано наукові статті вітчизняних науковців, офріційні сайти страхових компаній та сайт Міністерства фрінансів України. Під час виконання даного дослідження застосовано методи структурування, аналізу і узагальнення інфрормації.

Результати. У статті розкрито особливості програм медичного страхування за умов COVID-19. Для цього розглянуто зарубіжний досвід змін в політиці фрункціонування страховиків у різних країнах через пандемію. Проведено комплексне дослідження програм страхування від COVID-19 українських страхових компаній, визначено їх переваги та недоліки.

Висновки. Пандемія COVID-19 змусила страхові компанії змінити свою політику фрункціонування як у зарубіжних країнах, так і в Україні, переглянувши свої програми. Аналіз показав, що договори про страхування від COVID-19 на страховому ринку різних страхових компаній є подібними між собою і мають як переваги, які полягають у зменшенні фрінансового навантаження на хворого та наданні впевненості у фрінансовому забезпеченні й матеріальній компенсації збитків, так і недоліки.
\end{abstract}

КЛЮчОВІ СЛОВА: медичне страхування; договори медичного страхування; страхові програми; страхове покриття.

За всю історію свого існування людство пережило не одну пандемію і добре знає, які наслідки вона залишає після себе. На початку 2020 р. світ уразила пандемія COVID-19, яка швидкими темпами поширилась країнами світу та принесла великі економічні збитки. Безперечно, для кожної країни на сьогодні відоме таке поняття, як «економічна криза», яка, не попереджаючи про прихід, завжди завдавала суттєвої шкоди для економіки, проте пандемія COVID-19 стала новим випробуванням для світової економіки. Пандемія вірусу COVID-19 торкнулася кожної галузі, створила нові загрози для успішного існування будьякого бізнесу, в тому числі й страхових компаній, але навіть за таких несприятливих умов вони знаходять нові можливості для розвитку, переглядаючи умови своїх програм та підлаштовуючи їх під умови сучасності.

Мета дослідження: з'ясувати особливості програм медичного страхування за умов пандемiї COVID-19.

Матеріали і методи. Матеріалами для дослідження стали наукові статті вітчизняних науковців, офріційні сайти страхових компаній та сайт Міністерства фрінансів України. Під час виконання даного дослідження використано методи структурування, аналізу і узагальнення інфрормації.

Результати дослідження та їх обговорення. Незважаючи на те, що інфекційні захворювання підпадають під карантинні заходи, пандемії, епідемії, вони є виключенням зі страхових випадків практично у всіх країнах світу, враховуючи сучас-

(с) Н. Я. Климук, В. Л. Смірнова, Н. Я. Панчишин, 2021 ний стан розповсюдження пандемії COVID-19, страхові компанії вирішили переглянути умови своїх програм. Насамперед такий захист страховики пропонують медикам. Від захворюваності на COVID-19 розроблено пропозиції із страхування і для пацієнтів. Так, у середині березня 2020 р. багато страховиків із всього світу розмістили на власних веб-сайтах інформацію щодо змін у політиці в зв'язку з коронавірусом. Зокрема, у Китаї страховики, деякі страхові компанії розширили страхове покриття діючих полісів задля того аби оплатити витрати на лікування чи надати виплату в разі смерті через COVID-19. Інші медичні страховики ініціювали «Програми реагування в надзвичайній ситуації» задля того аби забезпечити оперативне врегулювання претензій для страхувальників. Додаткове покриття було надано для працівників охорони здоров'я й журналістам. У Сінгапурі та Гонконгу було запропоновано подібні механізми включення додаткового покриття ризиків від COVID-19 на безкоштовній основі. В Італії, а також у ряді інших європейських країн, великими страховими компаніями було створено окремі поліси безпосередньо з метою захисту страхувальників від ризику COVID-19 [1].

Український страховий ринок також вніс корективи в політику функціонування. Так, на сьогодні багато українських страховиків пропонує укладання договорів медичного страхування на випадок захворювання на COVID-19 [3]. Розроблена програма страхування від COVID-19 € дієвим інструментом фрінансового захисту. При- 
кладом такої компанії є страхова компанія USI «Ю. Ес. Ай.» - це інноваційна та сучасна страхова компанія, яка успішно фрункціонує на українському ринку страхових послуг і готова запропонувати широкий спектр страхових послуг. Зазначена компанія $є$ членом Асоціації «Страховий бізнес» та Ліги страхових організацій України, Асоційованим членом Моторного (транспортного) страхового бюро України (МТСБУ). Від кожного проданого страхового поліса компанією USI «Ю. Ес. Ай.» 5 \% йде на закупівлю засобів медичного призначення і медичних товарів для медичних закладів України [6]. Більш того, 23.02.2021 р. страхова компанія USI «Ю. Ес. Ай.» випустила перший в Україні унікальний страховий продукт VAC-COVID, що убезпечує від можливих негативних наслідків вакцинації страхувальника [2].

Через поширення вірусу COVID-19, компанія «Уніка», задля захисту здоров'я та життя співробітників і клієнтів, прийняла рішення про переведення офрісів страхової компанії на змінений формат роботи. Клієнти тепер мають можливість встановити та використовувати мобільний додаток «myUNIQA», окрім стандартної процедури звернення в медичний асистанс, який працює 24 години 7 днів на тиждень. Лікар-координатор, залежно від виду звернення, приймає рішення щодо запису до лікаря чи виклику швидкої медичної допомоги. Якщо лікар виявить підозру в хворого щодо захворювання на COVID-19, то транспортування, тестування і госпіталізація відбувається у чітко регламентовані установи, їх перелік визначено спеціальним розпорядженням МО3. Оплата договорів страхування можлива он-лайн без відвідування відділень страхової компанії [5].

Проведемо порівняння страхових програм від COVID-19 українських страхових компаній, а саме: «Арсенал Страхування», «Країна», «Оберіг», «Провідна», «Універсальна», «Уніка», «УПСК», «VUSO» (табл. 1).

Таблиця 1. Програми страхування від COVID-19 українських страхових компаній

\begin{tabular}{|c|c|c|c|}
\hline $\begin{array}{l}\text { Страхова } \\
\text { компанія }\end{array}$ & Програма & $\begin{array}{l}\text { Страхова } \\
\text { сума, грн }\end{array}$ & Страхове покриття \\
\hline $\begin{array}{l}\text { Арсенал } \\
\text { Страхування }\end{array}$ & $\begin{array}{l}\text { Захист від } \\
\text { COVID-19 }\end{array}$ & $\begin{array}{l}25000 i \\
100000\end{array}$ & $\begin{array}{l}\text { Залежно від програми: пневмонія - амбулаторне і } \\
\text { стаціонарне лікування; госпіталізація за умови тяжкого } \\
\text { перебігу хвороби; смерть застрахованого від COVID-19 }\end{array}$ \\
\hline Країна & $\begin{array}{l}\text { Захист від } \\
\text { COVID-19 }\end{array}$ & $\begin{array}{l}10000 \\
25000 \\
50000\end{array}$ & $\begin{array}{l}\text { Госпіталізація або смерть, які пов'язані з гострою } \\
\text { респіраторною хворобою COVID-19, спричиненою } \\
\text { коронавірусом SARS-CoV-2 }\end{array}$ \\
\hline Оберіг & $\begin{array}{l}\text { STOP- } \\
\text { коронавірус }\end{array}$ & 50000 & $\begin{array}{l}\text { Стаціонарне лікування COVID-19; смерть в результаті } \\
\text { COVID-19 }\end{array}$ \\
\hline Провідна & $\begin{array}{l}\text { Стоп. } \\
\text { Коронавірус }\end{array}$ & 50000 & $\begin{array}{l}\text { Стаціонарне лікування більше п'яти днів гострої } \\
\text { респіраторної інфекції, викликаної COVID-19 (до } 30 \text { днів); } \\
\text { смерть застрахованого від COVID-19 }\end{array}$ \\
\hline Універсальна & $\begin{array}{l}\text { Захист від } \\
\text { COVID-19 }\end{array}$ & $\begin{array}{c}50000 \text { та } \\
100000\end{array}$ & $\begin{array}{l}\text { Стаціонарне лікування COVID-19 понад } 5 \text { днів; смерть від } \\
\text { COVID-19 }\end{array}$ \\
\hline Уніка & $\begin{array}{l}\text { Страхування } \\
\text { від COVID-19 }\end{array}$ & 50000 & $\begin{array}{l}\text { Підтвердження діагнозу; амбулаторне і стаціонарне } \\
\text { лікування; смерть від COVID-19 }\end{array}$ \\
\hline УПСК & $\begin{array}{l}\text { Турбота 24/7: } \\
\text { розширення } \\
\text { COVID-19 } \\
\end{array}$ & 30000 & $\begin{array}{l}\text { Консультації та аналізи; поліклініка і стаціонар; смерть від } \\
\text { COVID-19 }\end{array}$ \\
\hline VUSO & $\begin{array}{l}\text { Страхування } \\
\text { від COVID-19 }\end{array}$ & 70000 & $\begin{array}{l}\text { Підтвердження діагнозу; амбулаторне і стаціонарне } \\
\text { лікування; смерть від COVID-19 }\end{array}$ \\
\hline
\end{tabular}

Джерело: склали автори на основі [1, 3, 4].

Варто зауважити, що всі зазначені програми $€$ доступними для клієнтів віком від 1 до 60 років. Умови страхового покриття в більшості $€$ схожими, а до страхових випадків належать інфікування вірусом COVID-19 (при наявності лабораторного підтвердження); лікування на стаціонарній та амбулаторній основі; смерть застрахованої особи через тяжку форму перебігу хвороби. Страхові суми в договорах страхування відрізняються і можуть сягати 50 000-100 000 грн. Проте, окрім переваг, зазначені поліси мають i недоліки, зокрема до таких можна віднести те, що покриття активується лише через два-три дні після офрормлення, а за умовами деяких програм дія страхового захисту починається 3 п'ятнадцятого календарного дня, який $€$ наступним за датою укладення договору. Таким чином, якщо страхувальник відчує перші симптоми хвороби протягом цих днів та зволікає зі зверненням до лікаря, очікуючи, аби договір набув чинності, він може суттєво знизити власні шанси на одужання, оскільки зволікання при захворюванні COVID-19 є неприпустими [1].

\section{Висновки}

Пандемія COVID-19 змусила страхові компанії змінити свою політику функціонування як у зарубіжних країнах, так і в Україні, переглянувши свої програми. Аналіз показав, що договори про стра- 
хування від COVID-19 на страховому ринку різних страхових компаній є подібними між собою і мають як переваги, які полягають у зменшенні фрінансового навантаження на хворого та наданні впевненості у фрінансовому забезпеченні й матеріальній компенсації збитків, так і недоліки. Оскільки зараз 2021 р., а ситуація з пандемією COVID-19 все ще є загостреною, то досліджуване питання не втрачає актуальності та потребує подальших досліджень.
Серед питань, що потребують подальших досліджень, можна виокремити питання попередження ймовірності невиконання страховими компаніями своїх зобов'язань у зв'язку з нестачею ліжко-місць для хворих у лікувальних закладах, обґрунтування економічних та організаційних засад запровадження добровільного соціального медичного страхування, а також розробки спільних програм для страхування ризиків пандемії на основі партнерства між органами державної влади та страховими компаніями.

\section{Список літератури}

1. Боднар О. А. Функціонування страхового ринку України в умовах пандемії COVID-19 [Електронний ресурс] / О. А. Боднар, В. В. Хоренженко, Ю. В. Татаренкова // Ефективна економіка. - 2020. - № 10. - С. 3-5. - Режим доступу : http://www.economy.nayka.com.ua/?op=1\&z=8268 (дата звернення 15.09.2021).

2. Ліга страхових організацій : страхова компанія [Електронний ресурс]. - Режим доступу : http://uainsur.com/ news/62122/ (дата звернення 16.09.2021).

3. Сосновська О. О. Розвиток медичного страхування в умовах COVID-19 / О. О. Сосновська, Г. О. Баліцька // Збірник наукових праць Університету державної фріскальної служби України. - 2020. - № 1-2. - С. 325-337.

4. Страхування від COVID-19: як убезпечити себе в умовах епідемії [Електронний ресурс]. - Режим доступу : https:// minfin.com.ua/ua/insurance/articles/strahovanie-ot-covid19-kak-obezopasit-sebya-v-usloviyah-еріdemii/ (дата звернення 17.09.2021).

5. Уніка : страхова компанія [Електронний ресурс]. - Режим доступу : https://uniqa.ua/ua/ (дата звернення 16.09.2021). 6. USI «Ю. Ес. Ай.» : страхова компанія [Електронний ресурс]. - Режим доступу : https://usi.net.ua (дата звернення 15.09.2021)

\section{References}

1. Bodnar, O.A., Khorenzhenko, V.V., \& Tatarenkova, Yu.V. (2020). Funktsionuvannya strakhovoho rynku Ukrayiny v umovakh pandemiyi Covid-19 [Functioning of the insurance market of Ukraine in the conditions of the Covid-19 pandemic]. Efektyvna ekonomika - Efficient Economy, 10, 3-5. Retrieved from: http://www.economy.nayka.com.ua/?op=1\&z=8268 [in Ukrainian].

2. Liha strakhovykh orhanizatsiy [League of insurance companies]. Retrieved from: http://uainsur.com/news/62122/ [in Ukrainian].

3. Sosnovskaya, O.O., \& Balitskaya, G.O. (2020). Rozvytok medychnoho strakhuvannya v umovakh COVID-19 [Development of health insurance in terms of COVID-19]. Zbirnyk naukovykh prats Universytetu derzhavnoï fiskalnoï sluzhby Ukraïny - Collection of scientific works of the University of the State Fiscal Service of Ukraine, 1-2, 325-337 [in Ukrainian].

4. (2021). Strakhuvannya vid COVID-19: yak ubezpechyty sebe v umovakh epidemiyi [COVID-19 insurance: how to protect yourself in an epidemic]. Retrieved from: https://minfin.com.ua/ua/insurance/articles/strahovanie-ot-covid19-kakobezopasit-sebya-v-usloviyah-epidemii/ [in Ukrainian].

5. (2021). Unika. Ofitsiynyy sayt strakhovoyi kompaniyi [Uniqa. Official site of the insurance company]. Retrieved from: https://uniqa.ua/ua/ [in Ukrainian].

6. (2021). USI «Yu.Es.Ai». Ofitsiynyy sayt strakhovoyi kompaniyi [USI "USI". Official site of the insurance company]. Retrieved from: https://usi.net.ua [in Ukrainian].

\section{HEALTH INSURANCE PROGRAMS AND THEIR FEATURES IN THE CONDITIONS OF COVID-19}

N. Ya. Klimuk, V. L. Smirnova, N. Ya. Panchyshyn

I. Horbachevsky Ternopil National Medical University, Ternopil, Ukraine

Purpose: to determine the specifics of health insurance programs in the context of the COVID-19 pandemic.

Materials and Methods. For the study were scientific articles of domestic scientists, official websites of insurance companies and the website of the Ministry of Finance of Ukraine. During the implementation of this study, methods of structuring, analysis and generalization of information were used.

Results. The article reveals the features of health insurance programs in the conditions of COVID-19. To do this, the foreign experience of changes in the policy of insurers in different countries in connection with the pandemic is considered. A comprehensive study of insurance programs from Covid-19 of Ukrainian insurance companies was conducted, their advantages and disadvantages were identified.

Conclusions. The COVID-19 pandemic has forced insurance companies to change their policies both in foreign countries and in Ukraine by revising their programs. The analysis showed that COVID-19 insurance contracts in the insurance market of different insurance companies are similar and have both advantages, which include reducing the financial burden on the patient and providing confidence in financial security and material compensation, as well as disadvantages.

KEY WORDS: health insurance; health insurance contracts; insurance programs; insurance coverage. 


\section{Відомості про авторів:}

Климук Наталія Ярославівна - кандидат технічних наук, доцент кафредри медичної інорорматики Тернопільського національного медичного університету імені І. Я. Горбачевського МОЗ України; тел.: +38(067) 352-51-63.

Смірнова Валентина Леонідівна - кандидат медичних наук, доцент кафедри громадського здоров'я та управління охороною здоров'я Тернопільського національного медичного університету імені І. Я. Горбачевського МОЗ України; тел.: +38(0352) 52-72-33.

Панчишин Наталія Ярославівна - кандидат медичних наук, доцент кафедри громадського здоров'я та управління охороною здоров'я Тернопільського національного медичного університету імені І. Я. Горбачевського МОЗ України; тел.: +38(0352) 52-72-33. 